\title{
How Countries Deal with the Covid-19 Pandemic: A Case Study of Indonesia and Slovakia
}

\author{
Adi Prasetyo Tedjakusuma ${ }^{1, *} \&$ Slavomír Rudenko ${ }^{2}$
}

\author{
${ }^{1}$ University of Surabaya, Surabaya, Indonesia \\ ${ }^{2}$ Pan-European University, Bratislava, Slovakia \\ * Corresponding author. Email: atedjakusuma@staff.ubaya.ac.id
}

\begin{abstract}
First reported in China in December 2019, the Covid-19 has now been growing to a very severe pandemic with more than 117 million cases worldwide only in one year. To minimize the pandemic impacts on the world's citizens, any country worldwide must take care of its respective citizens by carrying out various programs and policies to deal with the pandemic. As such, this paper presents what programs and policies have been done by countries worldwide by taking up a case study approach to reflect on the public policies of an emerging economy - Indonesia and an industrialized country - Slovakia. From the findings, it can be concluded that both Indonesia and Slovakia have done their best to mitigate the pandemic, although facing several different challenges based on their respective population structure, economic and political specificities.
\end{abstract}

Keywords: Covid-19, pandemic, vaccine, industrialized and emerging economy countries.

\section{INTRODUCTION}

First reported on December 31, 2019, in Wuhan city China, the Covid-19 has been growing to a very severe pandemic that attacks countries worldwide (Khanna et al 2020). According to Steffens (2020) only within 30 days, on January 29, 2020, the number of covid-19 cases grew to 6,000, spread over 18 countries worldwide, and increased around $1,300 \%$ to 83,000 cases on February 28, 2020. This rapid growth of the virus has attracted the world's attention, as evidenced that the World Health Organization (WHO), portrayed as the highest organization that is responsible for the world's public health conditions, declared the Covid19 situation to be a Public Health Emergency of International Concern on January 30, 2020, named the virus to be Covid-19 on February 20, 2020, and declared it as a global pandemic on March 11, 2020 (Khanna et al 2020).
Being the fifth world's pandemic after the Spanish Flu in 1918 (known as the first pandemic) that caused 50 million human deaths, Asian Flu in 1957 with 1.5 million deaths, Hong Kong Flu in 1968 with 1 million deaths, Pandemic Flu (H1N1) in 2009 with 300,000 deaths does not make the world able to minimize the impacts of this current pandemic (Liu et al 2020), as evidence that, as of March 5, 2021, the number of Covid-19 cases reaches 116 million with 2.5 million deaths (worlddometers 2021). Not to mention the socio-economic impacts of this pandemic to the world, where global economic growth declined from $2.4 \%$ in 2019 to $-4.2 \%$ in 2020 (OECD 2021), about 60 million people may be categorized as extreme poverty, 1.2 billion students are affected due to school/campus closures, 1.6 billion informal workers loss $60 \%$ of their income, global trade declined by $3 \%$, and about 1 billion loss of international tourists (UNDP 2020). 
To minimize the pandemic impacts on the world's citizens, it is an obligation of countries worldwide to take care of their respective citizens by carrying out various programs and policies to deal with the pandemic. Hence, it is interesting to discuss various programs, rules, or policies carried out by different countries. Considering that, this paper taking up a case study approach to reflect on the public policies of an emerging economy - Indonesia and an industrialized country - Slovakia.

\subsection{Covid 19}

Covid-19 stands for "CO" for Corona, "VI" for Virus, "D" for disease, and 19 represents the year when it was first identified. It is a contagious disease caused by the Corona virus with cough, fever, and shortness of breath and may cause fatality. People can be infected through direct contact with an infected person, touching their face, or even touching surfaces contaminated with the virus (UNICEF, WHO, IFRC 2020).

\subsection{Pandemic}

Pandemic is one disease spread and rate classifications that consist of endemic, epidemic, and pandemic. As the lowest classification, endemic refers to the spread of disease only in a particular community of a country. The second comes epidemic, where a disease spreads over many people within a country, and pandemic comes the highest as it spread over many countries or even continents (physiopedia 2021).

\subsection{An Emerging Economy Country}

An emerging economy country refers to an economy that is in the process of becoming a developed economy. They are characterized by low production rates, low education level, less developed infrastructure, a lower standard of living, limited access to health care and low income per capita (Banton \& Westfall 2020).

\subsection{An Industrialized Country}

Opposite to an emerging economy, an industrialized country refers to a country with high economic growth levels and security evidenced by the countries' high income per capita, income equality, high standard of living, high industrialization level, and prominent infrastructure (Majaski \& Boyle 2020)

\section{RESEARCH METHODS}

The current research applies a descriptive research method combining primary data of observations and interviews with residents in both countries and secondary data from newspapers, websites, articles, textbooks, and study centers from the beginning of Covid-19 in January 2020 to March 2021.

\section{RESULT AND DISCUSSION}

\subsection{Indonesia}

Located in Southeast Asia, Indonesia is known as the world's 10th largest economy in terms of purchasing power parity, the world's fourth most populous nation with about 275 million inhabitants, and a member of the G-20. In Indonesia, the first covid-19 case occurred on March 2, 2020, where a 64year age mother and her daughter were infected, and a year later, the cases are now 1.3 million with 37,000 deaths (worlddometers 2020). During the pandemic, Indonesia's economic growth shrank from $4.97 \%$ in Q4 of 2019 to $5.32 \%$ in Q2 of 2020 but bounced back to - 2.07 in Q4 of the same year (tradingeconomics 2021). Programs and policies that have carried out by the Indonesian government are as follows:

\subsubsection{Strategic Responses}

As the Indonesian government's very first response, on March 13, 2 days after the WHO declared the Covid-19 a pandemic or about ten days after first Indonesia's case, 
Indonesian President Joko Widodo established Covid-19 Response Acceleration Task Force under Presidential Decree No 7 of 2020. The Task Force was responsible directly to the President and under the National Agency for Disaster that works with the Ministry of Health, Indonesian Police, Army, and regional government. It was established to accelerate the handling of Covid-19 through the collaboration among relevant ministries and local government. Seeing the growing covid-19 cases in Indonesia, in April, the President declared the pandemic as a national disaster, while several provincial governments like Jakarta and East Java implemented a large-scale social restriction from April- September 2020. Moreover, four months after the establishment, on July 20, 2020, the task force was dissolved and replaced by the Covid-19 Mitigation and $\mathrm{Na}$ tional Economic Recovery Team led by Coordinating Minister for Economic Affairs. Compared to the task force that focused more on health, the recovery team that still exists focuses on health and recovers the Indonesian economy.

\subsubsection{Economic Sector Responses}

To stimulate its economy, on March 31, 2020, the Indonesian government ratified the Government Regulation no 1 Year 2020 in lieu of Law that administers additional 2020 State Budget Expenditure, worth IDR 405.1 trillion = USD 27 billion. The budget was allocated IDR 70 trillion for tax incentives and credit for business, IDR 110 billion for social protection, IDR 150 trillion for economic recovery, and IDR 75 billion for healthcare (Sekertariat Kabinet Republik Indonesia 2020). For healthcare spending, the budget is used to purchase medical equipment; give additional monthly incentives for medical workers that consist of USD 1,000 for a specialist, USD 750 for a general doctor, and USD 50 for a nurse; and give Social Security Agency subsidy for the public. For social protection, budget amounting to IDR 20 trillion is allocated for pre-employment card program, a program that prepares Indonesian to have working skills; basic need card where each individual receives IDR 200,000; Free electricity for $450 \mathrm{KVa}$ customers and $50 \%$ for using $900 \mathrm{KVa}$ customers; and low-cost housing subsidy. For tax incentive and economic stimulus, the budget is used to exempt income tax (for workers with income below IDR 200 million (USD 13,500)/year; reduce the corporate income tax from 25 to 22\%; support MSMEs, one of which by delaying MSMEs' debt payment for six months; and support local government spending.

\subsubsection{Mobility/Transportation Sector Re- sponses}

Aims to limit people (local people and foreigners) mobility, on March 31, 2020, The Ministry of Law and Human Rights issued Regulation No 11 of 2020 prohibiting foreigners from entering Indonesia even until now. While to limit local people's mobility, on April 23, 2020, the Ministry of Transportation issued Regulation no 25 of 2020 that prohibits homecomings, an annual routine activity for Muslims to come home to their hometown to celebrate Idul Fitri with families. To support this policy, the Ministry banned commercial flights from April 24May 7. On May 6, the Ministry allowed commercial flights with strict health protocol, and passengers must have negative PCR or rapid tests. While for local people mobility, the Indonesian government never implements a lockdown policy, but social restriction because Indonesian people get income from daily activities like food delivery and online taxi, thus lockdown will stop Indonesians' income and discourage Indonesian economy. The government carried out two different restrictions: a large-scale social restriction (PSBB) held on AprilSeptember 2020, and a community activities restriction (PPKM) held on JanuaryFebruary 2021. They were both aimed at limiting people's mobility but differed in some ways. 


\subsubsection{Education Sector Responses}

During the pandemic, on March 24, 2020, the Ministry of Education and Culture decided that students must Study From Home (SFH) and no national examination for primary and secondary education. This is quite a fascinating policy as previously Indonesia's national exams are known as the only determinant for primary and secondary students' graduation. The SFH policy was then extended until June 2021, known as the end of primary and secondary education's academic year. To support its SFH policy, the Ministry gives a monthly internet quota to all students and teachers from primary to university-level. Additionally, in parallel with a policy that prohibits foreigners from entering Indonesia, the Ministry of Education prohibits international students from entering Indonesia by not issuing new study permits since April 9, 2020 until now.

\subsubsection{Game Changer (Vaccine)}

To mitigate the pandemic, the world is now relying on vaccination, where it is expected that if the majority of the global population is vaccinated, herd immunity can be formed. In general, herd immunity refers to indirect protection for those who are not immune to the disease, which is formed by having the majority of a population is immune to a disease. Similar situation in Indonesia, by February 2022, the government intends to have vaccinated the majority of its population (i.e., 70\%) to form herd immunity. In light of providing this vaccine to Indonesian people, as of January 12 2021, the Indonesian government has sealed about 329 million doses of vaccine with 5 (five) vaccine companies: Sinovac (125 million doses), AstraZeneca (50 million doses), Novavax (50 million doses), Pfizer (50 million doses), and Covax AMC (54 million doses). Another 300 million doses to make about 600 million doses for vaccinating 170 million (70\% of 270 million Indonesian population) are on the negotiation process (Aldila 2021). The government has begun the first vaccine on January 13, 2021, where the Indonesian President was the first person vaccinated. There will be 4 (four) vaccination phases from January 2021-February 2022 (Sekertariat Kabinet Republik Indonesia 2021b). Four vaccination phases are shown in Table 1.

Table 1. Four Vaccination Phases in Indonesia

\begin{tabular}{|c|c|c|}
\hline $\mathrm{Ph}$ & Who & When \\
\hline $\mathrm{I}$ & $\begin{array}{l}\text { Healthcare workers and } \\
\text { equivalent }\end{array}$ & January-April 2021 \\
\hline II & $\begin{array}{l}\text { Indonesian Army, Indo- } \\
\text { nesian Police, Public } \\
\text { service officers, law en- } \\
\text { forcement officers + } \\
>60 \text { years old people }\end{array}$ & January-April 2021 \\
\hline III & $\begin{array}{l}\text { Vulnerable society seg- } \\
\text { ments, in terms of their } \\
\text { geospatial, social, and } \\
\text { economic circumstances }\end{array}$ & 2021-March \\
\hline IV & $\begin{array}{l}\text { The public and econom- } \\
\text { ic players }\end{array}$ & April 2021-Feb 2022 \\
\hline
\end{tabular}

\subsection{Slovakia}

Slovakia's response to Covid-19 shall be perceived out of a dual perspective - the national one and the one, based on the policies and the decisions of the country's membership in the European Union (EU).

The first confirmed Covid-19 case in Slovakia was reported on March 6, 2020. Since the infected person did not have a recent travel history, it was considered a secondary transmission case (UVZSR 2021). On March 7,2020 , the positivity was confirmed for the person above's son, having returned from Venice, Italy, named "patient 0". Although the first preventive measures were in place in late February 2020, before the first cases of positivity were even confirmed (such as certain limitations to mass events and gatherings), the events have taken full speed starting from March 12, 2020. On that day, the closing of schools and other educational institutions, the suspension of all crossborder transport, and an obligatory 14-day quarantine were announced. On March 15, 2020 , a state of emergency was announced 
for the first time. This was in place until June 14, 2020. During this first wave of the pandemic (roughly between March-May 2020), the country has reported considerably low case numbers, reaching a maximum 7day case count average of 60 on April 19, 2020 , and the death remained low with only double digits.

The situation had changed dramatically after the summer months. This was partly due to the interdependent trend throughout Europe and their spread across national borders, partly because of a lack of consistency on the national political scene and rather prolonged inactivity in setting up rules and posing new restrictions. This has led to a steep rise of cases between late SeptemberNovember 2020, following a plateau; eventually, a gentle decline in case counts after the nationwide antigen testing on October 31 and November 1, 2020. The situation in Slovakia between October 2020-March 2021 can be considered as a strong second wave of Covid-19. A new state of emergency was brought into force from October 1, 2020, and since then prolonged three times consecutively. Partial lockdowns, combining stricter measures and shorter periods of their relaxation, were gradually introduced between December 2020-March 2021 and still at the writing time.

\subsubsection{Political and social implications}

The Slovak response to Covid-19 undoubtedly is an example of becoming a victim of its previous success. Having been widely praised for its public policies, the timeliness and efficiency of applied measures as one of the best performers worldwide in the first wave of Covid-19, right after its outbreak and well into the third quarter of 2020 (Chubarova et al. 2020), the failure to act at the right time to slow down the growing case counts after the summer and in early autumn has brought the country to almost a collapse of its health care system in the beginning of 2021. Throughout January and February 2021, Slovakia, alongside the Czech Republic, has ranked among the countries with the highest Covid-19 deaths per capita globally.

The most obvious reasons may be observed in both the political and social moods. The political climates, on the one hand, and the general public response, on the other hand, seem to have performed as interconnected factors. A new government, established in March 2020, amidst the first wave of the pandemic, has marked the limits to the ability to lead a nation through a health crisis with having come to power with a pre-pandemic agenda. Even if led with the best intentions, the promises of anticorruption policies did not conform with the need to reach swift and appropriate public policy measures to tackle Covid-19 and communicate them clearly to the wide public. As a matter of direct consequence, the adherence to the anti-pandemic measures by the general public remained lax, even dismissive on a vast range of occasions. In January 2021, only 27 percent have approved the actions of the government. Although, in general terms, the reliance on the political decisions may undoubtedly fall amidst crises, such as in case of a pandemic, anywhere in the world, the disapproval would not have become as striking, would the decisions have been rational, foreseeable, and wellfounded. None of the political representation members (neither the government nor the legislative body) proved to the public that they knew what they were doing and how their decisions will influence their daily livelihoods. The persisting result in the society is a general mistrust and a much lower observance of anti-pandemic measures, given by several months of lockdowns and an atmosphere of pandemic fatigue compared to the first wave back in 2020 .

\subsubsection{Economic consequences}

The general economic activity was gravely influenced in the first wave between March-May 2020, given the general antipandemic measures all across the EU and 
globally. From Q3 of 2020, the economic indicators have stabilized gradually and were driven by exports and household consumptions. Overall, the GDP decrease has still recorded $-2.4 \%$, compared to a decline of $12.1 \%$ in $\mathrm{Q} 2$. The overall 2020 economic performance recorded a decline of $5.8 \%$. This decline was lower than the general EU, estimated to record $-7.2 \%$ (Grigaite et al. 2021). The predictions for 2021 might seem optimistic with an outlook of more than $4 \%$; the persisting pandemic may change the picture. The positive anticipations are based on a continued economic recovery after Q1 of 2021 and the ambitious schemes of the European Economic Recovery Plan (Ministry of Finance of the SR 2021), so-called Recovery and Resilience Facility (RRF), which should be worth $€ 672.5$ billion and address six different policy areas:

- the green transition

- digital transformation

- smart, sustainable and inclusive growth and jobs

- social and territorial cohesion

- health and resilience

- policies for the next generation, including education and skills (European council 2021).

The national measures to help people overcome the economic effects of the pandemic have included direct economic stimulus measures and employment-related measures and strategies (Ministry Work of Social Affairs and Family Slovak Republic 2021). Aimed initially as a temporary solution to address the first Covid-19 wave, these were already prolonged twice, as even at the time of writing substantial limitations, imposed by the government as measures to prevent the spread of the virus persist in daily economic life and include among others closures of all non-essential businesses, services, education facilities, etc. A periodic testing commitment is imposed upon the general public.

\subsubsection{Vaccine Rollout}

Slovakia's vaccination program is based on the joint vaccine acquisition for the whole EU and their distribution into the member countries accordingly by the share of their population on the EU total population (approximately 450 million). This approach was jointly decided in June 2020, allowing the EU to negotiate the purchase on behalf of its member states. Although it helped reduce the cost, after the first deliveries at the end of December 2020, it was clear that the negotiated amounts of vaccines will not be realistic due to severe production capacity and thus supply problems on the side of basically all relevant producers.

Contractually, the EU has secured a total of up to 2.6 billion doses from 6 different producers - Pfizer/BioNTech (600 million doses), Moderna (460 mil.), CureVac (405 mil.), AstraZeneca (400 mil.), Johnson \& Johnson/Janssen (400 mil.), and Sanofi/GSK (300 mil.). Negotiations with Novavax and Valneva are also underway (European Commission 2021a). Prioritizing the population of its member countries, the EU plans to provide all the overflow of the vaccine orders to the COVAX initiative, aimed at ensuring equitable access to the vaccines all over the world.

The vaccination in Slovakia began on December 26, 2020, when the leading Slovak infectologist, who has also become the face of the official vaccination campaign, has received his first Pfizer vaccine shot. So far, a total of 785.000 doses of vaccines have been applied at the time of writing (March 24, 2021). Approximately $1 / 3$ of the vaccinated persons have already received their second shot.

The expected time of 70 percent population has been vaccinated to reach herd immunity is in the summer months or at the latest until the planned full re-opening of school education in September 2021. Currently, as per the above table, registrations to receive a shot are open for the first five groups (korona 2021). 
Although the prioritized population groups are the older generations, senior care residents, and healthcare staff, the overall vaccination strategy specifies 11 different prioritized groups, as follows:

Table 2. Eleven vaccination groups in Slovakia

\begin{tabular}{|c|c|}
\hline Groul & Priority \\
\hline $\begin{array}{ll}\text { I } & \mathrm{H} \\
& \mathrm{ac} \\
\mathrm{W}\end{array}$ & $\begin{array}{l}\text { Healthcare staff, students of medical disciplines, } \\
\text { actively involved in medical care, other essential } \\
\text { workers in healthcare and social services }\end{array}$ \\
\hline II & General population above 85 years of age \\
\hline III & General population above 70 years of age \\
\hline IV & General population above 60 years of age \\
\hline $\mathrm{V}$ & General population above 55 years of age \\
\hline VI & General population above 50 years of age \\
\hline VII & General population above 45 years of age \\
\hline VIII & General population above 40 years of age \\
\hline IX & General population above 35 years of age \\
\hline $\mathrm{X}$ & General population above 30 years of age \\
\hline XI & Anyone older than 18 \\
\hline
\end{tabular}

\subsubsection{The European Digital Green Certifi- cate Initiative}

Since the first wave of Covid-19, the free movement, being one of the EU's fundamental freedoms, was restricted. In certain phases, and more through bilateral solutions rather than in a coordinated way, reaching all through the continent, the restrictions and limitations in the cross-border movement were softened and tightened again, reaching a stage after one year, where basically no movement over the borders within Europe is allowed anymore without a negative Covid19 test result and/or an obligation of quarantine.

In its strive to simplify the patchy rules, based on the public health measures and policies of each country, the European Commission has decided, on March 17, 2021, to create a so-called "Digital Green Certificate", facilitating cross-border travel and aiming towards a gradual return to the complete application of the principle of free movement of persons within the EU. The certificate will provide a unified proof, ap- plied all over the EU, about the fact that a person has been vaccinated, contain Covid19 test results for those who could not get a vaccine yet, or information on Covid-19 recovery. The certificate will be issued by the respective national authorities of each member state as a QR code with a digital signature (European Commission 2021b). It is expected that it shall be applied in practice from May/June 2021 to allow at least some relaxed form of a summer travel season. The initiative responds to the 2020 summer situation when the lifting of border restrictions to support the economies in countries with strong tourism sectors has led to the second wave of Covid-19, more or less all across Europe.

\section{CONCLUSION}

This paper presents various Covid-19 mitigation programs and policies carried out by Indophysionesia and Slovakia, providing a comparative study of different approaches in the Asian and European perspectives. Simultaneously, the study draws upon mechanisms applied in an emerging economy and an industrialized country facing the same global health crisis the world has not experienced for approx a century. From the above findings, it can be concluded that both Indonesia and Slovakia have done their best to protect their economies and, from a statistical point of view, to mitigate the pandemic. In Indonesia, it is proven that only about 1.3 million Indonesians, which is less than $0.5 \%$ of the total population, infected the virus, and the government's success stimulates economic growth from - 5.32\% in Q2 2020 to -2.07 in Q4 of the same year. Slovakia, being a member of the European Union, has applied both its national solutions, as well as joint European strategies, having become a country which was among the most successful in overcoming the first wave of Covid-19, right after its outbreak, to become a bad case scenario on the height of the second wave of 
this worldwide public health crisis. It has become clear that the economy, although suffering considerably over a long time span, will recover sooner or later. However, the wounds of society, experiencing grave daily failures or inactivity in managing the pandemic and understanding peoples' needs, will undoubtedly lead to lost faith in the country's political representation and institutions and may persist in a thriving postpandemic era.

\section{REFERENCES}

Aldila, Nindya. 2021. Menkes Budi: Indonesia Sudah Amankan 663 Juta Dosis Vaksin. Retrieved from https://kabar24.bisnis.com/read/20210112/15/134 1919/menkes-budi-indonesia-sudah-amankan663-juta-dosis-vaksin.

Banton, Caroline \& Peter Westfall. 2020. Third World. Retrieved from https://www.investopedia.com/terms/t/thirdworld.asp

Chubarova Tatiana, Ivan Maly, Juraj Nemec. 2020. Public policy responses to the spread of COVID19 as a potential factor determining health results: a comparative study of the Czech Republic, the Russian Federation, and the Slovak Republic. Central European Journal of Public Policy. 14(2):60-70

European Commission 2021a. Safe Covid-19 Vaccine for Europeans. Retrieved from https://ec.europa.eu/info/live-work-travel$\mathrm{eu} /$ coronavirus-response/safe-covid-19-vaccineseuropeans_en.

European Commission 2021b. Covid-19 digital green certificates. Retrieved from https://ec.europa.eu/info/live-work-traveleu/coronavirus- response/safe-covid-19-vaccineseuropeans/covid-19-digital-green-certificates_en, accessed on March 24, 2021.

European Council. 2021. Recovery Plan for Europe. Retrieved from https://www.consilium.europa.eu/en/policies/eurecovery-plan/

Grigaite K, J. Vega Bordell, K. Komazec, G. Gotti 2021. EU economic developments and projections. Retrieved from https: //www. europarl.europa.eu/RegData/etudes/BRIE/ 2020 /645 716/IPOL_BRI(2020)645716_EN.pdf.

Khanna C. R, Cicinelli V. M., Gilbert S. S., Honavar G. S, and Murthy S. V. G.2020. COVID19 pandemic: Lessons learned and future directions. Indian Journal of Ophthalmol 68(5): 703710.
Liu Y-C., Kuo R-L, and Shih S-R. 2020.COVID-19: The first documented corona virus pandemic in history. Biomedical Journal Vol. 43 (4), 328-333.

Majaski, Christina \& Michael Boyle. 2020. Developed Economy. Retrieved from https://www.investopedia.com/ terms/d/developed-economy.asp.

Ministry of Finance of the SR. 2021. The Macroeconomics is better than expected. Retrieved from https://www.mfsr.sk/sk/media/tlacove-spravy /makroekono micka-prognoza-je-lepsia-akoocakavalo.html.

Ministry of Investment, Regional Development and Informatization of the Slovak Republic. 2021. Who and when will be able to be vaccinated? Retrieved from https://korona.gov.sk/vakcinacia/

Ministry Work of Social Affairs and Family Slovak Republic.2021. Higher help within individual measure. $\quad$ Retrieved from https://www.pomahameludom.sk/

OECD. 2021. A Global Economy Recovery is in Sight . Retrieved from https://www.oecd.org/economicoutlook/

Physiopedia. 2021. Endemics,_Epidemics_and_Pandemics. Retrieved from https://www.physiopedia.com.

Sekertariat Kabinet Republik Indonesia. 2020. Press Statement of President of the Republic of Indonesia on Government Regulation in lieu of Law (Perppu) on State Finance Policy and Financial System Stability. Retrieved from https://setkab.go.id/en/press-statement-of- president-of-the-republic-of-indonesia-on- government-regulation-in-lieu-of-law-perppu-on-statefinance-policy-and-financial- system-stability/

Sekertariat Kabinet Republik Indonesia. 2021. COVID-19 Vaccination Program to be Carried Out in Four Phases. Retrieved from https://setkab.go.id/en/covid-19-vaccinationprogram-to-be-carried-out-in-four-phases/

Steffens, I., 2020, "A hundred days into the corona virus disease (COVID-19) pandemic", Euro Surveillance Journal 25(14): 1-4.

The United Nations Development Programme (UNDP) Report.2020. Brief \#2: Putting the UN framework for socio-economic response to COVID-19 into action: Insights. Retrieved from www.undp.org.

Tradingeconomics 2021. Indonesia GDP Annual Growth Rate2000-2021 Data | 2022-2023 Forecast. Retrieved from https://tradingeconomics.com/indonesia/ gdpgrowth-annual.

UNICEF, WHO, and IFRC Joint Document. 2020. Key Messages and Actions for COVID-19 Prevention and Control in Schools. Retrieved from www.who.int

UVZSR.2020. Slovensko zaznamenalo prvý potvrdený prípad ochorenia COVID-19. Retrieved 
from https://www.uvzsr.sk/index.php? option $=$ com_content $\&$ view $=$ article $\&$ id $=4061$ : sloven sko-zaznamenalo-prvy-potvrde-ny-pripad-

ochorenia-covid-19\&catid=250: $\quad$ koronavirus2019-ncov\&Itemid=153

Worlddometers.2021. Covid-19 Corona Virus Pandemic. Retrieved from https://www.worldometers.info/ coronavirus/ 